\title{
Phosphoinositide metabolism, aging and Alzheimer's disease
}

Citation for published version (APA):

Bothmer, J., \& Jolles, J. (1994). Phosphoinositide metabolism, aging and Alzheimer's disease. Biochimica et Biophysica Acta-Molecular Basis of Disease, 1225(2), 111-124. https://doi.org/10.1016/09254439(94)90068-X

Document status and date:

Published: 11/01/1994

DOI:

10.1016/0925-4439(94)90068-X

Document Version:

Publisher's PDF, also known as Version of record

\section{Please check the document version of this publication:}

- A submitted manuscript is the version of the article upon submission and before peer-review. There can be important differences between the submitted version and the official published version of record.

People interested in the research are advised to contact the author for the final version of the publication, or visit the DOI to the publisher's website.

- The final author version and the galley proof are versions of the publication after peer review.

- The final published version features the final layout of the paper including the volume, issue and page numbers.

Link to publication

\footnotetext{
General rights rights.

- You may freely distribute the URL identifying the publication in the public portal. please follow below link for the End User Agreement:

www.umlib.nl/taverne-license

Take down policy

If you believe that this document breaches copyright please contact us at:

repository@maastrichtuniversity.nl

providing details and we will investigate your claim.
}

Copyright and moral rights for the publications made accessible in the public portal are retained by the authors and/or other copyright owners and it is a condition of accessing publications that users recognise and abide by the legal requirements associated with these

- Users may download and print one copy of any publication from the public portal for the purpose of private study or research.

- You may not further distribute the material or use it for any profit-making activity or commercial gain

If the publication is distributed under the terms of Article $25 \mathrm{fa}$ of the Dutch Copyright Act, indicated by the "Taverne" license above, 


\title{
Phosphoinositide metabolism, aging and Alzheimer's disease
}

\author{
John Bothmer * and Jellemer Jolles \\ Department of Neuropsychology and Psychobiology, University of Limburg, P.O. Box 616, 6200 MD Maastricht, The Netherlands
}

(Received 2 June 1993; revised 11 October 1993; accepted 14 October 1993)

Key words: Phosphoinositide; Aging; Alzheimer's disease

\begin{abstract}
Contents
I. Introduction $\ldots \ldots \ldots \ldots \ldots \ldots \ldots \ldots \ldots \ldots \ldots \ldots \ldots \ldots \ldots \ldots \ldots \ldots \ldots \ldots \ldots \ldots \ldots \ldots$

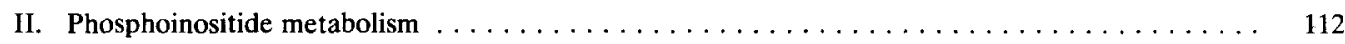

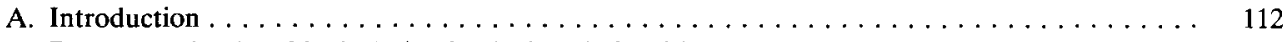

B. Receptor-stimulated hydrolysis of polyphosphoinositides $\ldots \ldots \ldots \ldots \ldots \ldots \ldots \ldots \ldots \ldots$

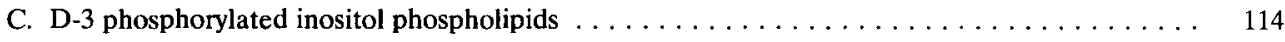

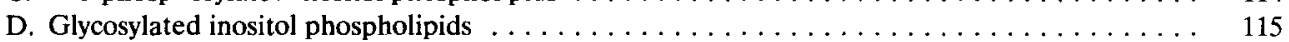

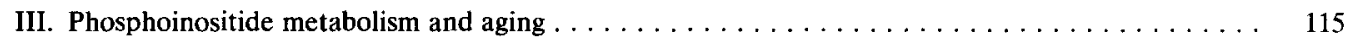

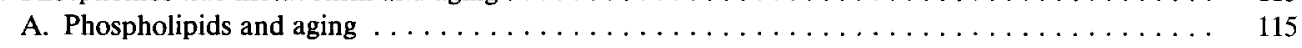

B. Receptor-mediated phosphoinositide hydrolysis and aging $\ldots \ldots \ldots \ldots \ldots \ldots \ldots \ldots \ldots \ldots$

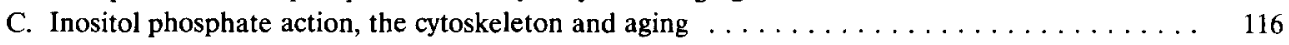

D. Protein kinases and aging $\ldots \ldots \ldots \ldots \ldots \ldots \ldots \ldots \ldots \ldots \ldots \ldots \ldots \ldots \ldots \ldots \ldots \ldots$
\end{abstract}

IV. Phosphoinositide metabolism and Alzheimer's disease $\ldots \ldots \ldots \ldots \ldots \ldots \ldots \ldots \ldots \ldots$

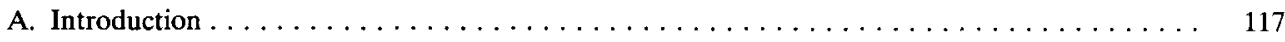

B. Phospholipids and Alzheimer's disease $\ldots \ldots \ldots \ldots \ldots \ldots \ldots \ldots \ldots \ldots \ldots \ldots \ldots$

C. Receptor-mediated phosphoinositide hydrolysis and Alzheimer's disease $\ldots \ldots \ldots \ldots \ldots \ldots 119$

D. Calcium release, protein phosphorylation and Alzheimer's disease $\ldots \ldots \ldots \ldots \ldots \ldots \ldots \ldots$

E. The cytoskeleton and Alzheimer's disease: neurofibrillary tangles $\ldots \ldots \ldots \ldots \ldots \ldots \ldots \ldots$

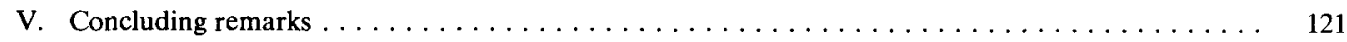

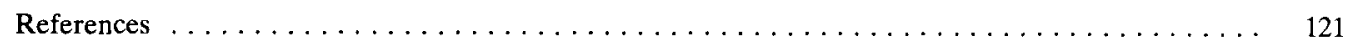

\section{Introduction}

In aging and age-associated disorders like Alzheimer's disease, the performance of various brain functions declines. A disturbance in signal transduction between brain cells could underlie some of these agerelated or Alzheimer's disease-related deficiencies. The metabolism of the phosphoinositides plays a crucial role in the signal transduction pathways of several neurotransmitters and neuropeptides. The present re-

\footnotetext{
* Corresponding author. Fax: $(+31)$ 043-671096.
}

view focuses on studies dealing with age-related and Alzheimer's disease-related changes in the metabolism of these inositol phospholipids. It is suggested that some of the changes in the metabolism of phosphoinositides with age can be explained by more general age-related changes in the physical properties of membranes. With respect to changes in phosphoinositide metabolism in Alzheimer's disease, there is growing evidence of specific changes in the inositol phospholipid system which could be related to the development of the characteristic cellular pathology of Alzheimer's disease. Future research in this area is of importance in order to determine whether these changes in phos- 
phoinositide metabolism are related to the cellular pathology of Alzheimer's disease and, if so, at what stage in the cascade of neurochemical events leading to the cellular pathology of Alzheimer's disease these changes occur.

In the twentieth century, the aging of the population is becoming an increasing problem in economically developed western countries. Aging is a problem because it is associated with decreased functioning. The most obvious changes with age in humans are grey hair, wrinkled skin, replacement of muscles by fat, but also a decline in the ability to see, hear and taste. Furthermore, decreased motor function, sleep, behaviour and cognitive functions, which probably all result from age-related deficiencies in the brain, are also observed. The effort and the expense of caring for disabled eldery people are enormous and still growing. More important, however, is the loss of the quality of life caused by age-related deficits in the last decades of life. Aging research should therefore focus on factors that influence successful aging, which seems to be more important than trying to prolong the maximal life-span of humans, by searching for the causative factor of aging. Biochemical research on cellular aging could lead to a better insight into the disturbed physiological functions associated with aging and probably to the prevention of many serious age-related diseases, such as various types of cancer, osteoporosis, athero- sclerosis, and age-related brain diseases, especially dementing conditions and Alzheimer's disease, which is the most common type of dementia. A decline in the performance of some brain functions is an important factor in the loss of the quality of life in eldery people. The good functioning of the brain is based on the communication between neurons, which communicate with neighbouring cells and with more distant cells by means of signal-sending as well as signal-processing systems. One of these signal-processing systems is the receptor-mediated phosphoinositide metabolism system. This review will focus on this system in the brain. A description of the phosphoinositide system and the interconversion of these phospholipids is given, followed by the changes that occur in phosphoinositide metabolism with age and Alzheimer's disease. Although a great deal is known about biochemical changes and the cellular pathology of aging and Alzheimer's disease (plaques and tangle formation, for example), this review will focus on those aspects that could be related to phosphoinositide metabolism.

\section{Phosphoinositide metabolism}

\section{A. Introduction}

The main characteristic of the brain is that its constituent cells communicate with each other and with other parts of the body. Much of this communication is

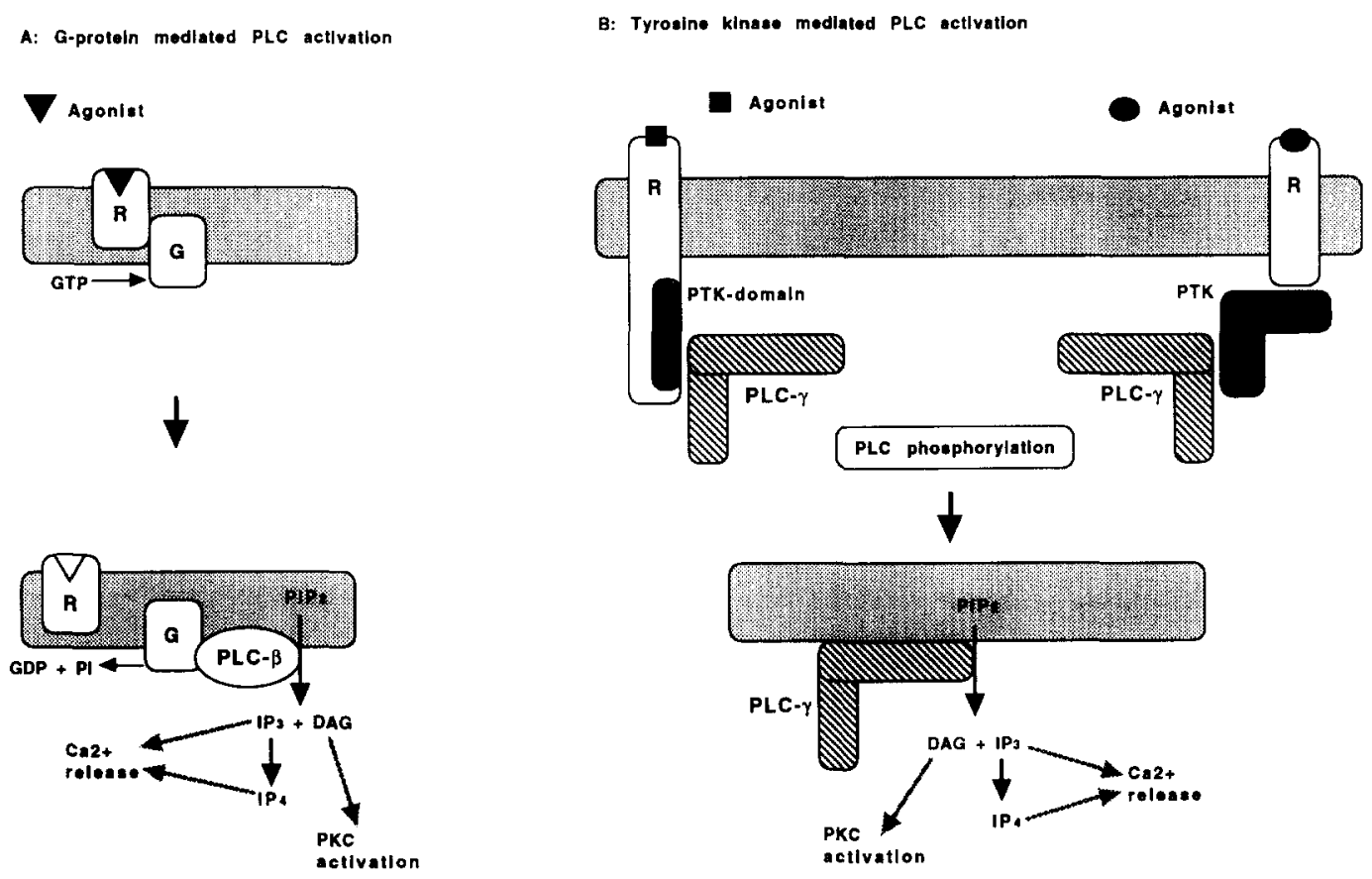

Fig. 1. Phosphoinositide hydrolysis by activated phospholipase C (PLC). A: Activation of PLC ( $\beta$-subtype) by G-protein (G) intermediated receptor (R) stimulation. For this role, the G-protein needs the binding of guanosine trisphosphate (GTP) which is hydrolysed in the activation proces of PLC- $\beta$. B: Activation of PLC ( $\gamma$-subtype) by protein tyrosine kinase (PTK) intermediated receptor stimulation. Left: PTK as a part of the receptor (PTK-domain), Right: PTK as an independent intermediating enzyme. PLC activation results in the hydrolysis of predominantly phosphatidylinositol bisphosphate $\left(\mathrm{PIP}_{2}\right)$ and consequently in the release of diacylglycerol (DAG) which activates protein kinase C (PKC) enzymes and inositol trisphosphate $\left(\mathrm{IP}_{3}\right)$ which, together with its phosphorylation product inositol tetrakisphosphate $\left(\mathrm{IP}_{4}\right), \mathrm{releases} \mathrm{Ca}^{2+}$ from intra- and extracellular sources. The mechanism of PLC- $\delta$ activation has not been elucidated (based on Ref. 9). 
achieved by chemical signals, such as neurotransmitters, neuropeptides and hormones, which are released by one cell and create a reaction in another cell. However, most chemical signals do not enter the target cells, so this extracellular signal has to be transformed into an intracellular signal. Phosphoinositides, a class of phospholipids which are relatively enriched in brain tissue [1], play an important role in one of the pathways of signal transduction through the plasma membrane. Phosphoinositides are phospholipids with the fully hydroxylated cyclohexane derivative inositol as polar head group and, predominantly, 1-stearoyl, 2arachidonoyl as fatty acid tails attached to the glycerol backbone [2]. Phosphatidylinositol, the most abundant phosphoinositide, can be phosphorylated by addition of one or more phosphates to the inositol ring with ATP as phosphate donor, resulting in the formation of polyphosphoinositides. The observation of Hokin and Hokin [3] that acetylcholine increased the incorporation of labelled phosphate into phosphatidate and phosphatidylinositol in brain slices was the first report of a connection between signal transduction and the metabolism of these acidic phospholipids. Since then, many investigators have studied the metabolism of phosphoinositides in relation to receptor-mediated signal transduction. Other (possible) functions of phosphoinositides have also received attention, such as the regulation of growth, cytoskeletal rearrangements, and protein anchoring to the membrane.

\section{B. Receptor-stimulated hydrolysis of polyphosphoinosi- tides}

An extracellular signal, such as a neurotransmitter or growth factor, initiates signal transduction through the membrane by binding to a specific receptor on the cell surface. This receptor is coupled to a 'second messenger-producing system' at the cytosolic side of the membrane, or to an ion channel. Receptors coupled to the phosphoinositide signal transduction mechanism are coupled to phospholipase C (PLC), a phosphoinositide-specific hydrolase. As shown in Fig. 1, this coupling could be achieved via an intermediate G-protein $[4,5]$, in analogy to the adenylate cyclase messenger system, or via tyrosine phosphorylation by a growth factor receptor containing a protein tyrosine kinase domain or an intermediate protein tyrosine kinase [6]. PLC activities have been purified from a wide variety of sources $[7,8]$. Comparison of amino acid sequences has indicated that the PLC's can be divided into three types (PLC- $\beta$, PLC- $\gamma$, and PLC- $\delta$ ) and that each type contains more than one subtype. Structure and regulation of activity of these PLC-subtypes has been reviewed extensively [9]. G-proteins require GTP for stimulation of second messenger generation [4]. The G-proteins which belong to a large homologous family of trimeric proteins $(\alpha, \beta$, and $\gamma$ subunits) that are always tightly associated have also been the focus of excellent reviews (see, e.g., Ref. 10). Besides stimulation of phosphoinositide hydrolysis by agonist-receptor interactions, inhibition of hydrolysis has also been observed after agonist-receptor interactions [11].

Because inositol trisphosphate $\left(\mathrm{I}(1,4,5) \mathrm{P}_{3}\right)$ is the first inositol metabolite which accumulates after receptor activation [12,13], the main candidate for receptorstimulated hydrolysis is the twice phosphorylated phosphatidylinositol 4,5-bisphosphate $\left(\mathrm{PI}(4,5) \mathrm{P}_{2}\right)$ [14], formed by the consecutive phosphorylation of phosphatidylinositol (PI) to phosphatidylinositol 4-phosphate (PI(4)P) by PI 4-kinase and of PI(4)P to $\mathrm{PI}(4,5) \mathrm{P}_{2}$ by PI(4)P 5-kinase $[15,16]$. However, the receptor-stimulated hydrolysis of PI and PIP has also been suggested $[17,18]$, resulting in the release of inositol monophosphate or diphosphate, respectively. Only a small portion of the inositol lipid pool is involved in signalling [19-21] and appears to be confined to the plasma membrane [22]. The hydrolysis of $\mathrm{PI}(4,5) \mathrm{P}_{2}$ results in the release of the second messengers inositol-1,4,5-trisphosphate $\left(\mathrm{I}(1,4,5) \mathrm{P}_{3}\right)$ and diacylglycerol (DAG) [23].

Water-soluble $\mathrm{I}(1,4,5) \mathrm{P}_{3}$ enters the cytosolic compartment and either binds to an $\mathrm{I}(1,4,5) \mathrm{P}_{3}$ receptor or is metabolized [24]. Binding to the $\mathrm{I}(1,4,5) \mathrm{P}_{3}$ receptor results in the release of $\mathrm{Ca}^{2+}$ from intracellular stores [25], probably the endoplasmic reticulum [26], via the opening of a $\mathrm{Ca}^{2+}$ channel [27]. This $\mathrm{Ca}^{2+}$ release from intracellular stores is followed by the entry of extracellular calcium [18]. It has been suggested that the entry of extracellular calcium is initiated by inositol tetrakisphosphate $\left(\mathrm{I}(1,3,4,5) \mathrm{P}_{4}\right)[28,29]$. However, both $\mathrm{IP}_{3}$ and $\mathrm{IP}_{4}$ are required for a full response [29,30], in which $\mathrm{I}(1,4,5) \mathrm{P}_{3}$ causes a transient rise in $\mathrm{Ca}^{2+}$ and the presence of $\mathrm{I}(1,3,4,5) \mathrm{P}_{4}$ leads to a sustained increase in $\mathrm{Ca}^{2+}$ levels, probably by replenishing the $\mathrm{I}(1,4,5) \mathrm{P}_{3}$ sensitive $\mathrm{Ca}^{2+}$ pool [31]. The complex metabolism of inositol phosphates has been reviewed recently $[30,32]$. Changes in the concentration of calcium play a central role in the regulation of various signalling and regulatory factors (such as several protein kinases and phospholipases) essential for neuronal functioning [33].

Besides $\mathrm{IP}_{3}$ as $\mathrm{Ca}^{2+}$-mobilizing second messenger, DAG is also released by the receptor-stimulated hydrolysis of $\mathrm{PIP}_{2}$ [23]. DAG remains in the plasma membrane and activates protein kinase $\mathrm{C}$ (PKC) in the presence of phosphatidylserine and calcium [34]. DAG increases the affinity of $\mathrm{PKC}$ for $\mathrm{Ca}^{2+}$, so that maximal $\mathrm{PKC}$ activity is possible at basal cytosolic $\mathrm{Ca}^{2+}$ concentrations [35]. However, several new members of the PKC family, whose activities are dependent on DAG/ phospholipid but independent of $\mathrm{Ca}^{2+}$, have been identified. Recently, the various PKC isoenzymes and their regulation mechanism have been reviewed by Azzi et al. [36]. The level of DAG is a function of its production from phosphoinositides but also other 
phospholipids like phosphatidylcholine, and its phosphorylation to PA or its degradation to its building blocks [37]. Upon cell stimulation, DAG is rapidly converted by diacylglycerol kinase to phosphatidic acid (PA) [38], which could have two functions: first, to initiate the resynthesis of the phosphoinositides, and second, to control the concentration of the second messenger DAG, thus acting as a regulator of PKC [39]. Although PA formed after DAG phosphorylation could be 'just' an intermediate in the resynthesis of phosphoinositides as described above, there are also indications that PA may directly mediate the inward movement of $\mathrm{Ca}^{2+}$ after activation of membrane receptors [40]. DAG breakdown is catalysed by DAG lipase resulting in the liberation of arachidonic acid (AA). The DAG phosphorylation product PA can be broken down to release AA by the activation of specific phospholipase $\mathrm{A}_{2}$ [41,42].

The $\mathrm{IP}_{3}$ branch and the DAG branch of the phosphoinositide signal cascade appear to act synergistically to phosphorylate proteins, the former by elevating $\mathrm{Ca}^{2+}$ concentrations resulting in an increased protein phosphorylation, and the latter by activating PKC $[18,37]$. The protein kinases regulate many other enzymes, ion channels, etc., by phosphorylation, ultimately resulting in a biological response [43].

Receptor-stimulated inositol phospholipid hydrolysis or the so-called 'PI effect' is found in various tissues of several species (listed in $[23,37,44])$, including, of course, the central nervous system (CNS). In their extensive review Fisher et al. [32] listed the receptors present on neurons and/or glia known to be linked to phosphoinositide turnover. They distinguish two groups of receptors: Category 1 receptors, which elicit a robust increase in inositol phospholipid turnover in tissue preparations of both the CNS and neurotumour cells, including muscarinic cholinergic, adrenergic, histaminergic, serotonergic, glutamatergic, and endothelin receptors; and Category 2 receptors, which elicit only a small increase in inositol phospholipid turnover in CNS-derived preparations, including purinergic, nerve growth factor, prostaglandin, bradykinin, vasopressin, oxytocin, thyrotropin-releasing hormone, and other receptors [32].

\section{D-3 phosphorylated inositol phospholipids}

The metabolism of inositol phospholipids has recently become more complex with the discovery of D-3 phosphorylated inositol phospholipids (Fig. 2). Whitman et al. [45] divided the PI kinases into two different types. Type 2 PI kinase appears to be a PI 4-kinase and is involved in the production of PI-4-P and ultimately $\mathrm{PI}-4,5-\mathrm{P}_{2}$, used for receptor-stimulated phosphoinositide hydrolysis [15]. Type 1 PI kinase appears to be a PI 3-kinase [46]. The D-3 phosphorylation of the novel inositol phospholipid (PI(3)P) was also shown by

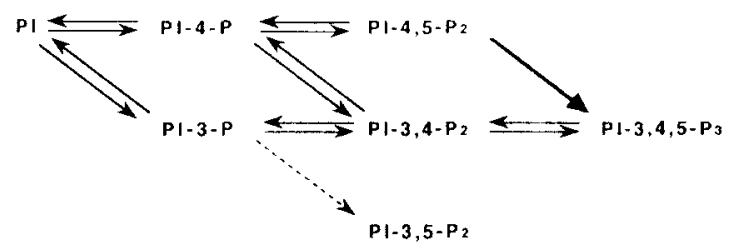

Fig. 2. Schematic diagram of phosphoinositide phosphorylation and dephosphorylation pathways. The 'conventional' pathway is shown above (PI $\leftrightarrow$ PI-4P $\leftrightarrow$ PI-4,5P 2 ). PI 3-kinase phosphorylates PI, PI-4-P and $\mathrm{PI} 4,5-\mathrm{P}_{2}$ at the D-3 position of the inositol ring. After receptor stimulation of PI 3-kinase activity, PI-4,5- $\mathrm{P}_{2}$ seems the preferred substrate of PI 3-kinase [50]. The existence of a PI-3-P 5-kinase activity is still controversial (based on Refs. 15,63).

Stephens et al. [47]. Besides PI(3)P, PI(3,4) $\mathrm{P}_{2}$ (with $\mathrm{PI}(4) \mathrm{P}$ as substrate) and $\mathrm{PI}(3,4,5) \mathrm{P}_{3}$ (with $\mathrm{PI}(4,5) \mathrm{P}_{2}$ as substrate) have also been detected [48]. After growth factor receptor stimulation, $\mathrm{PI}(3,4) \mathrm{P}_{2}$ and $\mathrm{PI}(3,4,5) \mathrm{P}_{3}$ are substantially raised [49], although Hawkins et al. [50] postulate that $\mathrm{PI}(3,4,5) \mathrm{P}_{3}$ is the primary candidate for the role of output signal and that $\mathrm{PI}(3,4) \mathrm{P}_{2}$ is 'just' a dephosphorylation product of $\mathrm{PI}(3,4,5) \mathrm{P}_{3}$. An inositol tetrakisphosphate-containing inositol phospholipid was also found by Traynor-Kaplan et al. [51] and Vadnal and Parthasarathy [52], who suggested that PIP $_{3}$ could be the parent compound of $\mathrm{IP}_{4}$. However, polyphosphoinositides phosphorylated in the D-3 position are poor substrates for phospholipase $\mathrm{C}$ from rat liver and bovine brain [53]. Probably just one enzyme is responsible for the production of these D-3 phosphorylated compounds, as purified type 1 PI 3-kinase can use PI, $\mathrm{PI}(4) \mathrm{P}$ and $\mathrm{PI}(4,5) \mathrm{P}_{2}$ as substrate with almost equal kinetic characteristics [54], although Cunningham et al. [55] also report the phosphorylation of $\mathrm{PI}(3) \mathrm{P}$ to $\mathrm{PI}(3,4) \mathrm{P}_{2}$ and $\mathrm{PI}(3,4) \mathrm{P}_{2}$ to $\mathrm{PI}(3,4,5) \mathrm{P}_{3}$.

The main feature of this enzyme activity or these enzyme activities is its (their) association with activated protein tyrosine kinases of growth factor receptors and oncogene products. These protein tyrosine kinases include pp60v-src, the polyoma middle $T$ antigen/ pp60c-src complex, the PDGF receptor, the CSF-1 receptor, the insulin receptor, and $p 68 \mathrm{v}$-ros, the transforming protein of the avian sarcoma virus UR2, as listed by Cantley et al. [56]. Therefore, PI 3-kinase seems to be involved in cell transformation and cell divison. This notion is strengthened by the results of mutation studies in which a loss of PI 3-kinase association coincides with a loss of the potency to transform cells [57-62]. However, cells in a terminally differentiated form, such as neutrophils and platelets, also produce D-3 phosphorylated phosphoinositides as a result of cell activation by agonists (listed in Ref. 63). Auger and Cantley [63] suggest that the novel polyphosphoinositides are involved in cytoskeletal reorganization because the effects found in neutrophils and platelets, as mentioned above, coincide with cytoskeletal changes, 
and a lack of association of PI 3-kinase appears to correlate with the lack of actin reorganization and mitogenic signals. In addition to this, some reports suggest a direct link between phosphoinositides and cytoskeletal components [64-66].

\section{Glycosylated inositol phospholipids}

Membrane-bound proteins can be attached to the membrane in various ways [67]. Until recently, this attachment was believed to be non-covalent in nature, by hydrophobic interaction of the protein with the membrane bilayer. However, in the last decade it has become clear that various membrane-bound proteins contain covalently bound lipid, in some cases a glycosylated phosphatidylinositol moiety [67]. The proteins utilizing glycosyl-phosphatidylinositol (GPI) as a membrane anchor are listed in reviews by Low [68] and Lisanti et al. [69]. Lisanti et al. [69] discuss the possible functions of this strange and complicated way of membrane attachment, and suggest functions in the cellular distribution of proteins, the lateral mobility of proteins, the exclusion of anchored proteins from clathrin-coated pits, and/or, the regulation of the release of proteins $[30,69]$.

In several cell types, a GPI has been described which shares the core structure of PIglucosamine and contains additional monosacharides, but which lacks ethanolamine and is not attached to protein [70]. It seems that these non-protein-bound GPIs, which are supposed to be located on the cytoplasmic side of the plasma membrane, can be hydrolysed by an insulinstimulated and phospholipase-mediated mechanism, resulting in the release of a novel second messenger, the inositol-glycan, and DAG [71,72]. This novel second messenger affects particular enzymes in vitro, but its mechanism of action is not known [73].

\section{Phosphoinositide metabolism and aging}

Phosphoinositide metabolism has many different aspects that are important for the functioning of cells, as we have seen above. According to Magnoni et al. [43], there is considerable evidence that the aging process affects this signalling cascade at different levels, from receptor availability to stimulation of second and third (protein phosphorylation) messengers. An overview of current knowledge of these different levels of the inositide signalling cascade in relation to aging (Table 1) is given below.

\section{A. Phospholipids and aging}

Phosphoinositides are normal components of the plasma membrane as mentioned earlier. The most remarkable change in the plasma membrane with age is the increase in the cholesterol/phospholipid ratio $[74,75]$. This increase in cholesterol/phospholipid ratio appears to correlate with the microviscosity of the membranes involved [76,77], which means that mem-

\section{TABLE I}

Phosphoinositide metabolism and aging

\begin{tabular}{|c|c|c|c|c|}
\hline Parameter of phosphoinos & tide metabolism & Tissue & Change with age & Ref. \\
\hline Lipid myo-inositol concen & rations & human anterior temporal cortex & $\downarrow$ & 82 \\
\hline Endogenous phospholipid & phosphorylation: & $\begin{array}{l}\text { (rat frontal-, parietal-, entorhinal-cortex, hippocampus, } \\
\text { striatum, thalamus, hypothalamus) }\end{array}$ & & \\
\hline & PA formation & rat hippocampus, frontal cortex, striatum, thalamus, & & \\
\hline & & hypothalamus & $\downarrow$ & 95,96 \\
\hline & $\mathrm{PIP}_{2}$ formation & frontal cortex, hypothalamus & $\downarrow$ & 95,96 \\
\hline & PIP formation & all structures & - & 95,96 \\
\hline PI kinase activity & & human temporal cortex & $\downarrow$ & 97 \\
\hline PIP kinase activity & & human temporal cortex & - & 97 \\
\hline Basal inositol phospholipic & labeling and hydrolysis & rat striatum, hippocampus, frontal cortex & $\downarrow$ & 93 \\
\hline Stimulated PLC activity: & carbachol & rat hippocampal slices & $\uparrow$ & 85 \\
\hline & carbachol & rat cerebral cortex slices & $\uparrow$ & 86,87 \\
\hline & carbachol & rat cortex, striatum & $\downarrow$ & 87,90 \\
\hline & noradrenaline & $\begin{array}{l}\text { rat cerebral cortex slices } \\
\text { rat cerebral cortex, striatum, hippo- }\end{array}$ & $\uparrow$ & 86 \\
\hline & 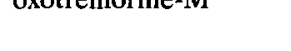 & campus, thalamus, hypothalamus, cerebellum & - & 88 \\
\hline & phenylepherine & rat thalamus and cerebral cortex & $\downarrow$ & 89 \\
\hline & phenylepherine & rat hippocampus & - & 89 \\
\hline & SKF38393 & rat striatum, hippocampus, frontal cortex & $\downarrow$ & 93 \\
\hline Stimulated $\mathrm{IP}_{4}$ formation: & carbachol & rat cerebral cortex slices & $\downarrow$ & 93 \\
\hline $\mathrm{IP}_{3}$ receptor density & & rat cerebellum & $\downarrow$ & 84 \\
\hline & & rat cerebral cortex & - & 84 \\
\hline $\mathrm{IP}_{3}$ induced $\mathrm{Ca}^{2+}$ release & & rat cerebral cortex microsomes & $\downarrow$ & 188 \\
\hline & & parotid cells & $\downarrow$ & 106 \\
\hline
\end{tabular}


brane fluidity decreases with age. The effects of changes in membrane fluidity on integral membrane proteins are discussed later. Other age-associated changes in plasma membrane components include an increased turnover of phospholipids in rat brain [78], an increased methylation of phosphatidylethanolamine by phospholipid methyltransferase I, although phospholipid methyl transferase II is unaffected in rat brain [79], a decreased synthesis of phosphatidylethanolamine and phosphatidylcholine, which seems to involve mostly neuronal rather than glial cells [80], a rapid loss of membrane lipids after 90 years of age in humans [81], and a decrease in lipid-myoinositol concentrations in human anterior temporal cortex (Brodman area 38) [82]. Biochemical changes in the membranes of cytoplasmic organelles of aging cells are mostly similar to those occurring in the plasma membrane [75]. However, lipid peroxidation is increased in the mitochondrial membranes of aged animals [83]. Lipofuscins, or age pigments, which are precipitated in lysosomes, are derived from the peroxidation of subcellular membranes containing polyunsaturated lipids (see Ref. 75 and refs. therein).

\section{B. Receptor-mediated phosphoinositide hydrolysis and aging}

Receptor-mediated phosphoinositide hydrolysis is one of the signal transduction systems by which a cell transforms an extracellular signal into an intracellular response via the release of intracellular messengers. A disruption of the phosphoinositide second messenger systems with age could be related to the impairment of neurological responsiveness and the behavioural deficits observed with aging [84]. The carbachol-stimulated release of inositol phosphates has been recently found to increase with age in hippocampal slices [85] and in cerebral cortex slices [86,87], and the noradrenaline-stimulated release of inositol phosphates has also been found to increase with age in cerebral cortex slices [86]. These effects occur in the absence of a change in the number of binding sites [85,87]. However, other investigators have reported no change in receptor-mediated inositol phosphate release (muscarinic receptor [88]). A decrease in inositol phosphate release was even reported after stimulation of cortical $\alpha$-1-adrenergic receptors [89], cortical muscarinic receptors [90] and striatal muscarinic receptors [87]. Besides age-related effects on agonist-stimulated inositol trisphosphate release, carbachol-stimulated $\mathrm{I}(1,3,4,5) \mathrm{P}_{4}$ formation was reduced by $44 \%$ in old rat cerebral cortex slices [91]. Aging of the rat brain could be associated with alterations in the basal turnover of the inositol cycle [92]. Undie and Friedman [93] observed that basal inositol phospholipid labeling and hydrolysis are decreased in the aging rat brain. These age-related changes were reversed by diet restriction which sug- gests that altered phospholipid content or metabolism may be responsible [93]. This notion was strengthened by the results of a study in which synaptosomal plasma membranes were phosphorylated with endogenous phospholipids as substrates. Endogenous PA formation decreased with age in whole brain, and PIP 2 formation decreased with age in the frontal cortex [94-96]. These effects were probably due to endogenous substrate availability because measurement of specific kinase activities, after solubilization of the enzymes and addition of exogenous substrates, revealed no, or only minor, age-related changes in rat brain cortex (Bothmer et al., submitted). In contrast to this latter finding, comparable solubilized protein fractions from human tissue (cerebral cortex) showed an age-related decline in PI kinase activity, whereas PIP kinase activity showed no age-related change [97].

Age-related changes in receptor-stimulated inositol phosphate release may be dependent upon the receptor-effector coupling or a change in the stoichiometry of the receptor-G-protein-phospholipase $\mathrm{C}$ interaction [90]. This latter idea is supported by the finding that in cultured rat heart myocytes, the inhibition of cAMP accumulation through Gi-proteins is lost with age [98] and that the decrease in adenylate cyclase activity in the submandibular salivary glands of aged rats seems partly due to changes in the availability of G-proteins [99]. An age-related uncoupling of the receptor-G-protein-phospholipase $\mathrm{C}$ interaction could be caused by age-related changes in membrane properties, such as membrane fluidity, as described before [74,100]. Uncoupling of the 'muscarinic receptor/cAMP inhibition' interaction in aged rat heart myocytes in culture is restored by phosphatidylcholine-liposome treatment [98]. Membrane viscosity also appears to correlate with $\alpha 1$-adrenergic signal transduction in the cerebral cortex of aged rats [101] and, in addition, chronic treatment with phosphatidylserine restores muscarinic cholinergic receptor deficits in the brains of aged mice [102]. The effect of membrane fluidity on the 'receptor-G-protein-second messenger production' interaction is accompanied by an effect of membrane fluidity on receptor binding with age $[100,103]$; however, receptor binding as a function of age will not be discussed here.

\section{Inositol phosphate action, the cytoskeleton and aging}

Age-related changes in the level of inositol phosphates released after receptor stimulation have been described. Inositol trisphosphate releases calcium from intracellular stores, and cytosolic free calcium is an important second messenger controlling many aspects of neuronal function and excitability. However, the cytosolic calcium concentration has to be normalized by calcium extrusion at the plasma membrane $(\mathrm{Na} / \mathrm{Ca}$ exchanger and $\mathrm{Ca}^{2+}$-ATPase) and by calcium sequestration in intracellular organelles (mitochondria and 
endoplasmic reticulum). Calcium homeostasis and its changes with age are reviewed by Gibson and Peterson [104]. The action of inositol polyphosphates in releasing $\mathrm{Ca}^{2+}$ from intracellular stores is thought to be affected by the aging process [105], as the density of inositol trisphosphate receptors is decreased in the cerebellum, but not in the cerebral cortex of old rats [84]. Furthermore, the amount of calcium released from microsomes by inositol trisphosphate decreases with age in rat brain [188] and parotid cells [106], and resting levels of cytosolic free calcium are decreased in fibroblasts from aged humans [107].

The cytoskeleton plays an important role in receptor-mediated phosphoinositide metabolism by keeping the receptors, G-proteins and enzymes involved together, as receptors are directly linked to the cytoskeleton [75], as are inositol phospholipid kinases, diacylglycerol kinase and phospholipase C $[108,109]$. Furthermore, D-3 phosphorylated inositol phospholipids seem to be involved in the processes of cytoskeleton turnover. In aging, there is a disequilibrium between polymer and monomer forms of tubulin and a disorganization of the cytoskeleton [75]. The microtubule-associated proteins MAP1 and MAP2, which contribute significantly to the polymerization of brain tubulin, are degraded to a greater extent in aged rat brain because of an increased proteolytic activity of cathepsin D [110]. The age-related changes in the cytoskeleton are probably partially due to age-related changes in $\mathrm{Ca}^{2+}$ homeostasis, as calcium/calmodulin-dependent kinase II is an important regulator of the neuronal cytoskeleton [111]. Because phosphoinositide metabolism is a regulator of $\mathrm{Ca}^{2+}$ homeostasis, age-related changes in the cytoskeleton could be related to age-related changes in phosphoinositide metabolism.

\section{Protein kinases and aging}

Several types of protein kinases are activated as a result of receptor-stimulated phosphoinositide hydrolysis. For example, calcium/calmodulin-dependent protein kinase is activated by the elevated cytosolic calcium concentrations as a result of the action of inositol trisphosphate, and protein kinase $\mathrm{C}$ is activated by diacylglycerol, the second messenger which is released simultaneously with inositol trisphosphate. PKC is reported to be modified during aging in various cerebral areas, as a result of either enzyme activity or substrate availability [43]. How aging affects the activity of calcium/calmodulin-dependent protein kinase needs to be explored.

In Sprague-Dawley rats, phorbol ester binding and PKC activity are reduced with age in the cortex, enhanced in the hippocampus and unmodified in the cerebellum [112]. At the level of the hypothalamus, PKC activity appears to decrease with age in contrast to pituitary PKC, which shows an age-related up-regu- lation [113]. Fisher 344 rats also show an age-related reduction in PKC activity in the cortex, but no changes in the hippocampus and the cerebellum [114]. The age-related impairment in PKC activity in rat brain cortex may affect transmitter release, because antibodies against the PKC substrate B-50 inhibit noradrenaline release, and, furthermore, B-50 phosphorylation is increased by depolarization [115]. In addition, the stimulatory action of activated PKC on serotonin release in the cortex of adult rats changes to an inhibition with age [114]. The age-related modifications of the PKC pathway in different cerebral areas and rat strains are reviewed by Magnoni et al. [43]. Hershkowitz et al. [103] have shown that a decrease in lipid fluidity, which occurs with age, results in a modulation of protein phosphorylation in synaptic membranes.

\section{Phosphoinositide metabolism and Alzheimer's dis- ease}

\section{A. Introduction}

Aging as defined in part 1 also includes age-associated brain disorders such as dementia. About $55-75 \%$ of the cases of adult-onset dementia are of the Alzheimer type. Alzheimer's disease (AD) generally occurs at ages greater than 65 years, but in a small number of cases it strikes people in their forties and fifties [116]. The diagnosis of AD is very difficult especially in the early stages, because the symptoms overlap with those seen in normal aging [117]. There is no certain means of diagnosis other than brain biopsy [118]. AD is characterized clinically by a progressive deterioration of memory, personality and intellect [119]. In addition to the clinical syndrome, $A D$ is characterized histochemically by the occurrence of neuritic plaques and neurofibrillary tangles. Plaques consist of a central core of amyloid fibrils surrounded by dystrophic neurites together with reactive microglia and astrocytes [120]. With increasing severity of dementia, these mature plaques are formed out of diffuse plaques which do not have a central core and are already present in very mildly demented peoples [121]. The sequence of $\beta / \mathrm{A} 4$, which is the major component of plaque cores, is encoded by a gene for the amyloid precursor protein (APP) [122]. APP spans the membrane once and has a large extracellular amino-terminal domain with a short carboxy-terminal cytoplasmic tail [122]. The $\beta / A 4$ sequence in APP begins close to the membrane on the extracellular side and ends partway through the putative transmembrane region [120]. Under normal conditions, the extracellular part can be released by enzyme action in the $\beta / \mathrm{A} 4$ region [123,124], resulting in the release of a soluble APP. In $\mathrm{AD}$ the $\beta / \mathrm{A} 4$ sequence is released intact, which means that there has to be an extracellular cleavage site and another site in the transmembrane region of APP. How 
an enzyme gains access to that transmembrane region is still unsolved. Several investigators hypothesize the release of $\beta / \mathrm{A} 4$ to be the primary cause of $\mathrm{AD}$, and think that all other aspects of $\mathrm{AD}$ are secondary events. The fact that a mutation of the APP gene, as in familial $\mathrm{AD}$, can give rise to all of the neuropathological hallmarks of $\mathrm{AD}$ without there being any other defect strongly suggests that amyloid mismetabolism and deposition is the seminal event in the pathogenesis of all cases of $\mathrm{AD}[120,125]$. According to this hypothesis neurofibrillary tangles would develop secondary to the deposition of $\beta /$ A4. However, Price et al. [121] have shown that the first development of tangles and plaques occurs in different parts of the brain. The composition of these neurofibrillary tangles are discussed in Section IV.E., The cytoskeleton and Alzheimer's disease: neurofibrillary tangles.

According to Selkoe [125], the difference between normal brain aging and $\mathrm{AD}$ is quantitative rather than qualitative, because normal non-demented subjects also develop at least a few senile plaques and neurofibrillary tangles, particularly in the hippocampus and other brain regions important for memory. Tangles appear with age in the olfactory nucleus, the parahippocampal gyrus and the hippocampus, but are rare in the neurocortex except in demented persons. Conversely, plaques may develop first in the neocortex, which implies that tangles and plaques first develop in different parts of the brain [121]. However, the aetiology and pathogenesis of $\mathrm{AD}$ are still not known. Therefore, because phosphoinositides are involved in various important cell functions, this review emphasizes the fact that $\mathrm{AD}$ is also characterized by changes in the metabolism of phospholipids and of phosphoinositides (Table II) in particular.

\section{B. Phospholipids and Alzheimer's disease}

Phospholipids are the main components of the membrane, and the condition of this membrane can influence the proteins attached to it, for instance receptors, G-proteins and enzymes, as mentioned above. ${ }^{31} \mathrm{P}$ NMR studies have demonstrated that there are increased levels of phosphomonoesters, possibly as the result of higher PLC activities, early in the course of $\mathrm{AD}$ and increased levels of phosphodiesters as the disease progresses [126]. The levels of phosphomonoesters are inversely correlated with the number of senile plaques, whereas the levels of phosphodiesters are positively correlated with the numbers of senile plaques [127]. These and additional findings resulted in the hypothesis that the earliest molecular/metabolic changes in $\mathrm{AD}$ result in elevated levels of phosphomonoesters in the neocortex and allocortex, followed by a cortical and subcortical elevation of phosphodiesters later in the course of the disease, which reflects cellular degeneration and death (see Ref. 126 and refs. therein). A physiologically relevant action of L-phosphoserine, one of the phosphomonoesters elevated in $\mathrm{AD}$, has been suggested because whole brain concentrations may reach over $1 \mathrm{mM}$ in $\mathrm{AD}$ and 1.-phosphoserine has close structural similarities to I-glutamate, which means that it could interact with the glutamate receptor [128].

Furthermore, there appears to be an increased degradation of phospholipids in AD brain (frontal, parietal and primary auditory cortex) as phosphatidylcholine and phosphatidylethanolamine levels and the levels of their precursors choline and ethanolamine are decreased in contrast to the levels of their deacylation products, which are increased [129]. These phospholipid abnormalities appear not to be an epiphenomenon of neurodegeneration but may be specific for the pathomechanism of AD [129]. In the anterior temporal cortex of AD brains, PI levels are significantly lower than in the same area of age-matched control brains [130]. Stokes and Hawthorne [130] have also reported that PIP and PIP $_{2}$ levels tend to decrease in $\mathrm{AD}$; however, these data may have been affected by

TABLE II

Phosphoinositide metabolism and Alzheimer's disease

\begin{tabular}{|c|c|c|c|}
\hline Parameter of phosphoinositide metabolism & Tissue & Change in $\mathrm{AD}$ & Ref. \\
\hline PI levels & cerebral anterior temporal cortex & $\downarrow$ & 130 \\
\hline PIP and PIP ${ }_{2}$ levels & cerebral anterior temporal cortex & $\downarrow$ (tendency) & 130 \\
\hline PI kinase activity & frontal, precentral, temporal and parietal cortex & $\downarrow$ & 148 \\
\hline PIP kinase activity & frontal, precentral, temporal and parietal cortex & - & 148 \\
\hline 'Type 1' PI kinase activity & temporal cortex & $\downarrow$ & 149,150 \\
\hline PI and PIP kinase activity & blood platelets of $\mathrm{AD}$ donors & - & 152,153 \\
\hline m1-muscarinic receptor-Gprotein coupling & temporal cortex & - & 143 \\
\hline Gprotein $\alpha$-subunit levels & frontal cortex, hippocampus, cerebellum & - & 144 \\
\hline Abberant accumulation of PLC $-\delta$ & temporal cortex, hippocampus & $\uparrow$ & 145 \\
\hline Abberant accumulation of PLC $\beta,-\lambda 1$ and $-\lambda 2$ & temporal cortex, hippocampus & - & 145 \\
\hline Basal PLC activity & frontal cortex, hippocampus & - & 147 \\
\hline Stimulated PLC activity: $5-\mathrm{HT}$ & frontal and parietal cortex & - & 141 \\
\hline bradykinin & fibroblasts of $\mathrm{AD}$ donors & - & 146 \\
\hline Number of $\mathrm{IP}_{3}$ binding sites & temporal cortex, hippocampus & $\downarrow$ & 154 \\
\hline
\end{tabular}


the long and variable post-mortem delay, because polyphosphoinositides are rapidly degraded post-mortem [131]. The composition of brain membranes is thus altered in $\mathrm{AD}$, and this probably results in functionally significant alterations in the biophysical properties of brain cell membranes [132].

\section{Receptor-mediated phosphoinositide hydrolysis and Alzheimer's disease}

As in aging, the different levels of the inositide signalling cascade are or could be involved in $A D$. Fowler et al. [133] hypothesized that there is a decline in the functional integrity of receptor-mediated signal transduction mechanisms, such as cAMP release and the inositol phosphate/diacylglycerol release systems, in $\mathrm{AD}$, although most studies of receptor function in $\mathrm{AD}$ have considered only the receptor recognition site [134]. Interestingly, several of the neurotransmitter systems affected in AD, such as the cholinergic, serotonergic and noradrenergic systems, are coupled to these effector systems [133]. However, receptor binding and receptor number have been reviewed extensively [134136] and will not be discussed.

'Receptor-G-protein-second messenger producer' coupling in AD brain membranes had not been studied until recently. Stimulated adenylate cyclase activity appears to be reduced in the superior temporal cortex and hippocampus of $\mathrm{AD}$ brains $[137,138]$, although in another study stimulated adenylate cyclase activity in frontal cortex, hippocampus, caudate nucleus and cerebellum preparations was unaffected [139]. In addition, Cowburn et al. [140] report a widespread impairment of G-protein-stimulated adenylate cyclase activity in the frontal cortex of $\mathrm{AD}$ brains. This impairment occurs in the absence of an altered enzyme catalytic activity and is unlikely to be the result of non-diseaserelated factors associated with the nature of the terminal illness of individuals. The coupling of the 5hydroxytryptamine-1A receptor, which has been reported to be coupled to both adenylate cyclase and phospholipase C, to G-proteins appears to be intact in frontal and parietal cortices of $A D$ brain [141]. The Gi-protein-mediated inhibition of adenylate cyclase activity is also not impaired in four regions of $A D$ brain (temporal cortex, frontal cortex, angular gyrus and cerebellum) [142]. In addition, the coupling of M1muscarinic receptors, which preferentially activate phospholipase C, to G-proteins in the temporal cortex of $\mathrm{AD}$ brain is also unaffected [143]. According to McLaughlin et al. [144], changes in the amount of G-protein $\alpha$-subunits are not a feature of the frontal cortex, hippocampus and cerebellum of AD brain, in contrast to the aberrant accumulation of phospholipase $\mathrm{C}-\delta$ in the temporal cortex and hippocampus of $\mathrm{AD}$ brains. This accumulation of phospholipase $C-\delta$ but not of other PLC subtypes is suggested to be a crucial event that may ultimately contribute to the formation of paired helical filaments [145]. Because there is very little tritium labelling of polyphosphoinositides after incubation of autopsy samples, receptor-mediated inositol phospholipid breakdown in postmortem material is difficult to measure [133]. The bradykinin-induced formation of $\mathrm{IP}_{3}$ and $\mathrm{IP}_{2}$ was measured in fibroblasts from $\mathrm{AD}$ donors, but did not differ from that of normal aged donors [146]. The enzyme activity of PLC does not appear to be affected in the frontal cortex and hippocampus of $\mathrm{AD}$ brains [147], thus a possible change in inositol phosphate release can only be caused at the receptor-G-protein-PLC coupling level, at the level of receptor density, or at the level of $\mathrm{PIP}_{2}$ supply (activity of PI and PIP kinases). In cytosolic preparations of brain cortex (frontal, precentral, temporal and parietal cortices) of $\mathrm{AD}$ patients, PI kinase activity appears to be decreased compared with that of age-matched control subjects, whereas PIP kinase activity was not affected [148]. Because AD patients with an 'age of first symptoms' above 75 years had a higher PI kinase activity in the temporal cortex than $\mathrm{AD}$ patients with an 'age of first symptoms' below 75 years, PI kinase activity could possibly be used to divide $\mathrm{AD}$ patients into subgroups characterized by the age of onset of the disease [97]. The greatest decline in PI kinase activity in the cortex of $\mathrm{AD}$ brain was found in the cytosolic fractions, in contrast to the PI kinase activity in integral membrane protein fractions. Cytosolic PI kinase activity was inhibited by Triton X-100 but was relatively insensitive to adenosine [149], which are features characteristic of type 1 PI kinase or PI 3-kinase [15]. These results suggest that just one type of PI kinase is affected in the cortex of AD brains, namely type $1 \mathrm{PI}$ kinase which seems to be involved in the regulation of the turnover of the cytoskeleton [150]. Therefore, a decrease in the activity of this type of PI kinase could be closely related to the cellular pathology of $\mathrm{AD}$, as neurofibrillary tangles are partially composed of incorrectly metabolized cytoskeletal components. Despite the indication that, firstly, disease-specific abnormalities in the brain, such as those occurring in diseases like Parkinson's disease, Huntington's disease and depression, can be reflected in blood platelets [151], and secondly, PI kinase activity is substantially decreased in the cortex of $\mathrm{AD}$ brains, PI kinase activity in platelets from $\mathrm{AD}$ patients was not different from that of control platelets $[152,153]$.

\section{Calcium release, protein phosphorylation and Alzheimer's disease}

Because phosphoinositide-mediated signal transduction results in changes in calcium homeostasis and protein kinase activities, this part of the review deals with age- and Alzheimer's disease-related changes in these aspects. 
It is not known whether the release of inositol phosphates is altered in AD brain, mainly because of the technical problems mentioned above. However, the number of $\mathrm{IP}_{3}$ binding sites essential for calcium release in the temporal cortex and hippocampus is severely reduced $(50-70 \%$ loss) in $\mathrm{AD}$ brains [154]. The same technical problems for the measurement of inositol phosphate release also exist for the measurement of calcium concentrations and fluxes in $\mathrm{AD}$ brains. Cytosolic free calcium and cell spreading of calcium is decreased in fibroblasts from $\mathrm{AD}$ donors [107]. Furthermore, $\mathrm{Na}^{+} / \mathrm{Ca}^{2+}$ exchange activity is increased in the frontal cortex, temporal cortex and hippocampus of $\mathrm{AD}$ brain tissue, which is interpreted as indicating that neurons surviving in brain regions suffering the greatest degeneration as a result of $A D$ have increased $\mathrm{Na}^{+} / \mathrm{Ca}^{2+}$ exchange activity [155]. According to Mattson et al. [156], a disturbed calcium homeostasis, resulting in higher intracellular calcium concentrations, together with a disturbed inositol phospholipid metabolism, could be involved in neurofibrillary degeneration through the activation of protein kinases, because tau, a microtubule-associated protein, is abnormally phosphorylated in paired helical filaments.

Elevated calcium levels and activation of PKC both induce an increased paired helical filament-tau immunoreactivity in neuronal cell cultures, and addition of the PKC inhibitor H-7 blocks the increase in immune reactivity [156]. Furthermore, PKC is able to phosphorylate tau $[157,158]$ as well as neurofilament proteins $[159,160]$.

Protein phosphorylation and the occurrence of senile plaques also seem to be related. A synthetic peptide corresponding to a region of amyloid precursor protein is phosphorylated by PKC, suggesting that amyloid precursor protein could be a physiological substrate of PKC [161]. Furthermore, PKC immunoreactivity is present in mature plaques [162,163], whereas diffuse plaques only show immunoreactivity for the PKC subtype $\beta$ II. This PKC $\beta$ II subtype is probably an early biochemical marker of $\mathrm{AD}$, because diffuse plaques do not show immunoreactivity for senile plaque markers such as casein kinase II, tau or paired helical filaments [164]. Interestingly, this $\beta$ II PKC subtype is strongly associated with the cytoskeleton and is probably responsible for the phosphorylation of the growthassociated GAP43 or B-50 protein [165]. In the frontal cortex of AD brains, the level of PKC and the in vitro phosphorylation of its $86 \mathrm{kDa}$ substrate are decreased, and there is a translocation of $\mathrm{PKC}$ activity from the particulate pool to the soluble cytosolic pool [166].

A possible function of $\mathrm{PKC}$ is the regulation of protein tyrosine phosphorylation $[167,168]$. The protein tyrosine kinase activity in the particulate fraction of frontal cortex appeared to decrease two-fold, whereas cytosolic protein tyrosine kinase activity was not affected in AD brains compared to control brains [169]. However, the amount of two (55 and $60 \mathrm{kDa}$ ) phosphotyrosine immunoreactive polypeptides appeared to be increased in the frontal cortex and hippocampus of $\mathrm{AD}$ brains [169]. Because tyrosine kinase activity probably regulates PI 3-kinase activity, these findings could be directly related to the decreased PI kinase activity in AD brain cortex as proposed by Jolles et al. [148] and Bothmer et al. [150].

\section{E. The cytoskeleton and Alzheimer's disease: neurofibril- lary tangles}

As we have seen above (section II.C), the D-3 phosphorylated phosphoinositides are involved in growth factor signalling and in the regulation of cytoskeleton turnover. A prominent feature in $\mathrm{AD}$ brains is the abnormal accumulation of markedly insoluble filamentous material within neuronal cell bodies and neurites [170]. These neurofibrillary tangles are found in several neurodegenerative diseases besides $\mathrm{AD}$, such as postencephalitic Parkinson's disease, Guam Parkinsonism dementia complex, dementia pugulistica, and Down's syndrome [116]. Neurofibrillary tangles are widely distributed in AD brains, especially in the temporal and frontal cortices, hippocampus, some parts of the brainstem and hypothalamus. Microscopically, they appear as bundles of paired helical filaments of which a microtubule-associated protein, called tau, is an important constituent [171-173]. Under normal conditions, tau acts as a promotor and stabilizer of tubule polymerization [174]. It has been suggested that tau is abnormally phosphorylated in paired helical filaments [171, $175,176]$, a notion that is supported by the fact that the monoclonal antibody for normal tau recognizes tau in paired helical filaments only after treatment with alkaline phosphatase [173,177,178]. A68 protein in AD appears to be composed of several tau isoforms in a phosphorylated state which affects their electrophoretic mobility [179]. This abnormal phosphorylation of tau has been demonstrated in AD and Down's syndrome $[179,180]$. Paired helical filament-tau appears to contain $12 \mathrm{~mol}$ of phosphate per mol of tau, in contrast to normal tau from the brain of $A D$ and control brain, which contains approximately $3 \mathrm{~mol}$ of phosphate per mol of tau [181]. Because phosphorylation by cAMP-dependent protein kinase inhibits the degradation of tau by calpain, it is suggested that phosphorylation has a role in regulating the degradation of tau. In addition, abnormal phosphorylation could result in a protease-resistant tau, which could contribute to the formation of paired helical filaments in $\mathrm{AD}$ [182]. Because of the important function of tau in promoting and stabilizing tubule polymerization, a disturbance in the phosphorylation of tau could possibly lead to destabilization of the cytoskeleton and 
ultimately to degeneration of axons and dendrites, which occurs in $\mathrm{AD}$ [183]. Among other proteins, only ubiquitin has been convincingly shown to be a part of the paired helical filaments [184], although there are indications that tropomyosine, a microfilament protein [185], neurofilament proteins [186] and MAP 2 and 5 [187] are also constituents of paired helical filaments.

The D-3 phosphorylated phosphoinositides seem to be involved in cytoskeletal reorganization because a lack of association of PI 3-kinase appears to correlate with a lack of actin reorganization and mitogenic signalling [71]. It has been suggested that the key enzyme in the metabolism of these D-3 phosphorylated phosphoinositides is specifically affected in AD $[149,153]$. Therefore, a change in the metabolism of these phosphoinositides in $\mathrm{AD}$ could be closely related to the cytoskeletal changes in AD described above.

\section{Concluding remarks}

A disturbed signal transduction in the brain could underlie various age-related and Alzheimer's diseaserelated deficiencies. However, some of the age-related changes in the metabolism of phosphoinositides, as described in this review, could be explained by more general changes in the physical properties of membranes with age and in Alzheimer's disease. Thus in future research into age-related changes it will be important to correlate the findings with a biophysical parameter of the membrane, for example membrane fluidity. With respect to Alzheimer's disease, there is growing evidence that changes in the metabolism of phosphoinositides could be related to the characteristic cellular pathology of AD. Therefore it would be important to locate, by a better integration of the different areas of research, at what stage in the cascade of neurochemical events leading to the cellular pathology of Alzheimer's disease the changes in the phosphoinositide metabolism occur. Changes in the metabolism of brain phosphoinositides during aging and in Alzheimer's disease are potentially important because of the key role of phosphoinositides in several signal transduction pathways and in processes essential for cell functioning. A challenge for future research is to identify relationships between age-related changes in these pathways and processes, and the different biochemical and pathological changes that occur in aging and Alzheimer's disease. Considerable evidence suggests that the metabolism of phosphoinositides could be very important in this respect.

\section{References}

1 Hawthorne, J.N. and Kai, M. (1970) in Handbook of neurochemistry (Lajtha A., ed.), pp. 491-508. Plenum Press, New York.
2 Hawthorne, J.N. (1982) in New comprehensive biochemistry. Vol. 4, Phospholipids (Hawthorne, J.N. and Ansell, G.B., eds.), pp. 263-278. Elsevier, Amsterdam.

3 Hokin, M.R. and Hokin, L.E. (1953) J. Biol. Chem. 203, 967-977.

4 Litosch, I. (1987) Biochem. J. 244, 35-40.

5 Strnad, C.F., Parente, J.E. and Wong, K. (1986) FEBS Lett. 206, $20-24$.

6 Iwashita, S. and Kobayashi, M. (1992) Cell. Signalling 4, 123-132.

7 Baldassare, J.J., Henderson, P.A. and Fisher, G.J. (1989) Biochemistry 28, 6010-6016.

8 Rhee, S.G., Suh, P.-G., Ryu, S.-H. and Lee, S.Y. (1989) Science 244, 546-550.

9 Rhee, S.G. and Choi, K.D. (1992) J. Biol. Chem. 267, 1239312396.

10 Taylor, C.W. (1990) Biochem. J. 272, 1-13.

11 Linden, J. and Delahunty, T.M. (1989) TIPS 10, 114-120.

12 Burgess, G.M., McKinney, J.S., Irvine, R.F. and Putney, J.W. (1985) Biochem. J. 232, 237-243.

13 Irvine, R.F., Angard, E.E., Letcher, A.J. and Downes, C.P. (1985) Biochem. J. 229, 505-511.

14 Berridge, M.J., Dawson, R.M.C., Downes, C.P., Heslop, J.P. and Irvine, R.F. (1983) Biochem. J. 212, 473-482.

15 Carpenter, C.L. and Cantley, L.C. (1990) Biochemistry 29, 11147-11156.

16 Downes, C.P. and MacPhee, C.H. (1990) Eur. J. Biochem. 193 , $1-18$.

17 Wilson, D.B., Neufeld, E.J. and Majerus, P.W. (1985) J. Biol. Chem. 260, 1046-1050.

18 Berridge, M.J. (1987) Ann. Rev. Biochem. 56, 159-193.

19 Fain, J.N. and Berridge, M.J. (1979) Biochem. J. 180, 655-661.

20 Billah, M.M. and Lapetina, E.G. (1982) J. Biol. Chem. 257, 12705-12708.

21 Monaco, M.E. and Woods, D. (1983) J. Biol. Chem. 258, 1512515129.

22 Rana, R.S., Kowluree, A. and MacDonald, M.J. (1986) Arch. Biochem. Biophys. 245, 411-416.

23 Berridge, M.J. (1984) Biochem. J. 220, 345-360.

24 Catt, K.J., Hunyady, L. and Balla, T. (1991) J. Bioenerg. Biomembr. 23, 7-27.

25 Streb, H., Irvine, R.F., Berridge, M.J. and Schulz, I. (1983) Nature 306, 67-69.

26 Streb, H., Bayerdorffer, E., Haase, H., Irvine, R.F. and Schulz, I. (1984) J. Membr. Biol. 27. Smith, J.B., Smith, L. and Higgins B.L (1985) J. Biol. Chem. 260, 14413-14416.

28 Irvine, R.F. and Moor, R.M. (1986) Biochem. J. 240, 917-920.

29 Morris, A.P., Gallacher, D.V., Irvine, R.F. and Peterson, O.H. (1987) Nature 330, 653-655.

30 Berridge, M.J. and Irvine, R.F. (1989) Nature 341, 197-205.

31 Irvine, R.F., Moor, R.M., Pollock, W.K., Smith, P.M. and Wreggett, K.A. (1988) Philos. Trans. R. Soc. Lond. B. 320, 281-298.

32 Fisher, S.F., Heacock, A.M. and Agranoff, B.W. (1992) J. Neurochem. $58,18-38$.

33 Kennedy, M.B. (1989) TINS 12, 417-420.

34 Nishizuka, Y. (1984) Nature 308, 693-698.

35 Nishizuka, Y. (1988) Nature 334, 661-665.

36 Azzi, A., Boscoboinik, D. and Hensey, C. (1992) Eur. J. Biochem. 208, 547-557.

37 Hokin, L.E. (1985) Ann. Rev. Biochem. 54, 205-235.

38 Kanoh, H., Yamada, K. and Sakane, F. (1990) TIBS 15, 47-50

39 Nishizuka, Y. (1986) Science 233, 305-312.

40 Putney, J.W. Jr., Weis, S.J., Van De Walle, C.M. and Haddas, R.A. (1980) Nature 284, 345-347.

41 Billah, M.M., Lapetina, E.G. and Cuatrecasas, P. (1981) J. Biol. Chem. 256, 5399-5403. 
42 Lapetina, E.G. and Billah, M.M. (1981) Agents Actions 11, $536-537$.

43 Magnoni, M.S., Govoni, S., Battaini, F. and Trabucchi, M. (1991) Life Sci. 48, 373-385.

44 Abdel-Latif, A.A. (1986) Pharmacol. Rev. 38, 227-272.

45 Whitman, M., Kaplan, D., Roberts, T. and Cantley, L. (1987) Biochem. J. 247, 165-174

46 Whitman, M., Downes, C.P., Keeler, M., Keller, T. and Cantley, L. (1988) Nature 332, 644-646.

47 Stephens, L., Hawkins, P.T. and Downes, C.P. (1989) Biochem. J. 259, 267-276.

48 Auger, K.R., Serunian, L.A., Soltoff, S.P., Libby, P. and Cantley, L.C. (1989) Cell 57, 167-175.

49 Downes, C.P. and Carter, A.N. (1991) Cell. Signalling 3, 501-513.

50 Hawkins, P.T., Jackson, T.R. and Stephens, L.R. (1992) Nature $358,157-159$

51 Traynor-Kaplan, A.E., Harris, A.L., Thompson, B.L., Taylor, P. and Sklar, L.A. (1988) Nature 334, 353-356.

52 Vadnal, R.E. and Parthasarathy, R. (1989) Biochem. Biophys. Res. Comm. 163, 995-1001.

53 Serunian, L.A., Haber, M.T., Fukui, T., Kim, J.W., Rhee, S.G., Lowenstein, J.M. and Cantley, L.C. (1989) J. Biol. Chem. 264, 17809-17815.

54 Carpenter, C.L., Duckworth, B.C., Auger, K.R., Cohen, B., Schaffhausen, B.S. and Cantley, L.C. (1990) J. Biol. Chem. 265 19704-19711.

55 Cunningham, T.W., Lips, D.L., Bansal, V.S., Caldwell, K.K., Mitchell, C.A. and Majerus, P.W. (1990) J. Biol. Chem. 265, 21676-21683

56 Cantley, L.C., Auger, K.R., Carpenter, C., Duckworth, B., Graziani, A., Kapeller, R. and Soltoff, S. (1991) Cell 64, 281-302.

57 Whitman, M., Kaplan, D.R., Schaffhausen, B., Cantley, L. and Roberts, T.M. (1985) Nature 315, 239-242.

58 Kaplan, D.R., Whitman, M., Schaffhausen, B., Raptis, L., Garcea, R.L., Pallas, D., Roberts, T.M. and Cantley, L. (1986) Proc. Natl. Acad. Sci. USA 83, 3624-3628.

59 Courtneidge, S.A. and Heber, A. (1987) Cell 50, 1031-1037.

60 Fukui, Y, and Hanafusa, H. (1989) Mol. Cell. Biol. 9, 1651-1658.

61 Chan, T.-O., Tanaka, A., Bjorge, J.D. and Fujita, D.I. (1990) Mol. Cell. Biol. 10, 3280-3283.

62 Varticovski, L., Daley, G.Q., Jackson, P., Baltimore, D. and Cantley, L.C. (1991) Mol. Cell. Biol. 11, 1107-1113.

63 Auger, K.R. and Cantley, L.C. (1991) Cancer Cell. 3, 263-270.

64 Yu, F.-X., Sun, H.-Q., Janmey, P.A. and Yin, H.L. (1992) J. Biol. Chem. 267, 14616-14621.

65 Surridge, C.D. and Burns, R.G. (1992) Biochemistry 31, 61406144.

66 Forscher, P. (1989) TINS 12, 468-474.

67 Low, M.G. (1987) Biochem. J. 244, 1-13.

68 Low, M.G. (1989) Biochim. Biophys. Acta 988, 427-454.

69 Lisanti, M.P., Rodriguez-Boulan, E. and Saltiel, A.R. (1990) J. Membr. Biol. 117, 1-10.

70 Saltiel, A.R. and Cuatrecasas, P. (1988) Am. J. Physiol. 255, cl-c11.

71 Saltiel, A.R. and Cuatrecasas, P. (1986) Proc. Natl. Acad. Sci. USA 83, 5793-5797.

72 Saltiel, A.R., Fox, J.A., Sherline, P. and Cuatrecasas P. (1986) Science 233, 967-972.

73 Saltiel, A.R. (1991) J. Bioenerg. Biomembr. 23, 29-41.

74 Calderini, G., Bonetti, A.C., Battistella, A., Crews, F.T. and Toffano, G. (1983) Neurochem. Res. 8, 483-492.

75 Naeim, F. and Walford, R.L. (1985) in Handbook of the biology of aging (Finch, C.E. and Schneider, E.L., eds.), pp. 272-289. Van Nostrand Reinhold, New York.
76 Rivnay, B., Globerson, A. and Shinitzky, M. (1978) Eur. J. Immunol. 8, 185-189.

77 Rivnay, B., Globerson, A. and Shinitzky, M. (1979) Mech. Aging Dev. 10, 71-79

78 Pettegrew, J.W., Panchalingham, K., Withers, G., McKeag, D. and Strychor, S. (1990) J. Neuropathol. Exp. Neurol. 49, 237-249.

79 Crews, F.T., Calderini, G., Battistella, A. and Toffano, G. (1981) Brain Res. 229, 256-259.

80 Gaiti, A., Brunetti, M., Piccinin, G.L.W., Oelk, K. and Porcelatti, G. (1982) Lipids 17, 291-296.

81 Svennerholm, L., Bostro K., Helande C.G. and Jungbje, B. (1991) J. Neurochem. 56, 2051-2059.

82 Stokes, C.E., Gillon, K.R.W. and Hawthorne, J.N. (1983) Biochim. Biophys. Acta 753, 136-138.

83 Hegner, D. (1980) Mech. Aging Dev. 14, 101-118.

84 Li, P.P., Vecil, G.G., Green, M.A. and Warsh, J.J. (1991) Neurobiol. Aging 13, 89-92.

85 Tandon, P., Mundy, W.R., Ali, S.F., Nanry, K., Rogers, B.C. and Tilson, H.A. (1991) Pharmacol. Biochem. Behav, 38, 861-867.

86 Nalepa, I., Pintor, A., Fortuna, S., Vetulani, J. and Michalek, H. (1989) Neurosci. Lett. 107, 195199

87 Mundy, W., Tandon, P., Ali, S. and Tilson, H. (1991) Life Sci. 49, 97-102.

88 Surichamorn, W., Abdallah, E.A. and EL-Fakahany, E.E. (1989) J. Pharmacol. Exp. Ther. 251, 543-549.

89 Burnett, D.M., Bowyer, J.F., Masserano, J.M. and Zahniser. N.R. (1990) J. Pharmacol. Exp. Ther. 225, 1265-1270.

90 Pietrzak, E.R., Wilce, P.A. and Shanley, B.C. (1990) Neurochem. Int. 17, 593-598.

91 Kurian, P., Narang, N. and Crews, F.T. (1992) Neurobiol. Aging $13,521-526$.

92 Undie, A.S. and Friedman, E. (1992) Neurobiol. Aging 13, 505-511.

93 Undie, A.S. and Friedman, E. (1993) J. Gerontol. 48, B62-B67.

94 Bothmer, J., Markerink, M. and Jolles, J. (1990) Neurochem. Int. 17, 27-33.

95 Bothmer, J., Markerink, M. and Jolles J. (1990) in From Gene to Man (Van Bezooijen, C.F.A., Ravid, R. and Verhofstad, A.A.J., eds.), pp. 186-189. J.H. Pasmans Publishers, The Hague, The Netherlands.

96 Bothmer, J., Markerink, M. and Jolles, J. (1992) Neurochem. Int. 21, 223-228.

97 Jolles, J., Bothmer, J., Markerink, M. and Ravid, R. (1993) Dementia 4, 81-86.

98 Moscona-Amir, E., Henis, Y.I. and Sokolovski, M. (1989) Biochemistry 28, 7130-7137.

99 Ahmad, S.N., Alam, S.Q. and Alam, B.S. (1990) Archs. Oral Biol. 35, 885-890.

100 Heron, D.S., Shinitzky, M., Hershkowitz, M. and Samuel, D. (1980) Proc. Natl. Acad. Sci. USA 77, 7463-7467.

101 Miyamoto, A., Araiso, T., Koyama, T. and Oshika, H. (1990) J. Neurochem. 55, 70-75.

102 Gelbmann, C.M. and Muller, W.E. (1991) Neurobiol. Aging 13, 45-50.

103 Hershkowitz, M., Heron, D., Samuel, D. and Shinitzky, M. (1982) Progr. Brain Res. 56, 419-434.

104 Gibson, G.E. and Peterson, C. (1987) Neurobiol. Aging 8, 329 343.

105 Barritt, G.J. (1987) Neurobiol. Aging 8, 357-359.

106 Ishikawa, Y., Gee, M.V., Ambudkar, I.S., Bodner, L., Baum, B.J. and Roth, G.S. (1988) Biochim. Biophys. Acta 968, 203-210.

107 Peterson, C., Ratan, R.R., Shelanski, M.L. and Goldman, J.E. (1986) Proc. Natl. Acad. Sci. USA 83, 7999-8001. 
108 Grondin, P., Plantavid, M., Sultan, C., Breton, M., Mauco, G. and Chap, H. (1991) J. Biol. Chem. 266, 15705-15709.

109 Payrastre, B., Van Bergen en Henegouwen, P.M.P., Breton, M., den Hartigh, J.C., Plantavid, M., Verkleij, A.J. and Boonstra, J. (1991) J. Cell Biol. 115, 121-128.

110 Matus, A. and Green, G.D.J. (1987) Biochemistry 26, 8083-8086.

111 Harris, J.K. and DeLorenzo, R.J. (1987) Neurobiol. Aging 8, 359-361.

112 Battaini, F., Del Vesco, R., Govoni, S. and Trabucchi, M. (1990) Neurobiol. Aging 11, 563-566.

113 Battaini, F., Del Vesco, R., Govoni, S., Moresco, R.M. and Trabucchi, M. (1990) in Aging brain and dementia: New trends in diagnosis and therapy (Battistin, $L$. and Gerstenbrand, F., eds.), pp. 169-187, Alan R. Liss, New York.

114 Friedman, E. and Wang, H.-Y. (1989) J. Neurochem. 52, 187192.

115 Dekker, L.V., De Graan, P.N.E., Oestreicher, A.B., Versteeg, D.H.G. and Gispen, W.H. (1989) Nature 342, 74-76.

116 Iqbal, K. (1991) in Alzheimer's disease: Basic mechanisms, diagnosis and therapeutic strategies (Igbal, K., McLachlan, D.R.C., Winblad, B. and Wisniewski, H.M., eds.), pp. 1-5. Wiley, Chichester, UK.

117 Jolles, J. and Hijman, R. (1983) in Aging of the brain (Gispen, W.H., and Traber, J., eds.), pp. 227-250. Elsevier, Amsterdam.

118 Tanzi, R.E., George-Hyslop, P.St. and Gusella, J.F. (1991) J. Biol. Chem. 266, 20579-20582.

119 Advokat, C. and Pellegrin, A.I. (1992) Neurosci. Biobehav. Rev. $16,13-24$.

120 Hardy, J. and Allsop, D. (1991) TIPS 12, 383-388.

121 Price, J.L., Davis, P.B., Morris, J.C. and White, D.L. (1991) Neurobiol. Aging 12, 295-312.

122 Tanzi, R.E., George-Hyslop, P.H.St. and Gusella, J.F. (1989) TINS 12, 152-158.

123 Esch, F.S., Keim, P.S., Beattie, E.C., Blacher, R.W., Culwell, A.R., Oltersdorf, T., McClure, D. and Ward, P.J. (1990) Science $248,1122-1124$

124 Sisodia, S.S., Koo, E.H., Beyreuther, K., Unterbeck, A. and Price, D.L. (1990) Science 248, 492-495.

125 Selkoe, D.J. (1991) Scientific American 265, 40-47.

126 Pettegrew, J.W. (1989) in Biological markers of Alzheimer's disease (Boller, F., Katzman, R., Rascol, A., Signoret, J.L. and Christen, Y., eds.), pp. 83-104. Springer, Berlin.

127 Pettegrew, J.W. and Klunk, W.E. (1990) in Imaging, cerebral topography and Alzheimer's disease (Rapoport, S.R., Petit, H., Leys, D. and Christen, Y., eds.), pp. 159-165.

128 Klunk, W.E., McClure, R.J. and Pettegrew, J.W. (1991) J. Neurochem. 56, 1997-2003.

129 Nitsch, R.M., Blusztajn, J.K., Pittas, A.G., Slack, B.E., Growdon, J.H. and Wurtman, R.J. (1992) Proc. Natl. Acad. Sci. USA $89,1671-1675$.

130 Stokes, C.E. and Hawthorne, J.N. (1987) J. Neurochem. 48, 1018-1021.

131 Dawson, R.M.C. and Eichberg, J. (1965) Biochem. J. 96, 634643.

132 Zubenko, G.S. (1986) Brain Res. 385, 115-121.

133 Fowler, C.J., O'Neill, C., Garlind, A. and Cowburn, R.F. (1990) TIPS 11, 183-184.

134 Morgan, D.G., May, P.C. and Finch, C.E. (1988) in Receptors and ligands in neurological disorders (Sen, A.K. and Lee, T., eds.), pp. 120-147. Cambridge University Press, U.K.

135 Whitehouse, P.J. (1987) Alz. Dis. Assoc. Disord. 1, 9-28.

136 Quirion, R., Aubert, I., Lapchak, P.A., Schaum, R.P., Teolis, S., Gauthier, S. and Araujo, D.M. (1989) TIPS 10 (suppl.), 80-84.

137 Cowburn, R.F., Fowler, C.J., Garlind, A., Alafuzoff, I., Nilsson,
L., Winblad, B. and Bergstrom, L. (1991) J. Neurol. Neurosurg. Psychiat. 54, 748-749.

138 Ohm, T.G., Bohl, J. and Lemmer, B. (1991) Brain Res. 540, 229-236.

139 Bergstrom, L., Garlind, A., Nilsson, L., Alafuzoff, I., Fowler, C.J., Winblad, B. and Cowburn, R.J. (1991) J. Neurol. Sci. 105, 225-233.

140 Cowburn, R.F., O'Neill, C., Ravid, R., Alafuzoff, I., Winblad, B. and Fowler, C.J. (1992) J. Neurochem. 58, 1409-1419.

141 O'Neill, C., Cowburn, R.F., Wiehager, B., Alafuzoff, I., Winblad, B. and Fowler, C.J. (1991) Neurosci. Lett. 133, 15-19.

142 Cowburn, R.F., O'Neill, C., Ravid, R., Winblad, B. and Fowler, C.J. (1992) Neurosci. Lett. 141, 16-20.

143 Pearce, B.D. and Potter, L.T. (1991) Alz. Dis. Ass. Dis. 5, 163-172.

144 McLaughlin, M., Ross, B.M., Milligan, G., McCulloch, J. and Knowler, J.T. (1991) J. Neurochem. 57, 9-14.

145 Shimohama, S., Homma, Y., Suenaga, T., Fujimoto, S., Taniguchi, T., Araki, W., Yamaoka, Y., Takenawa, T. and Kimura, J. (1991) Am. J. Pathol. 139, 737-742.

146 Huang, H.-M., Toral-Barza, L., Thaler, H., Tofel-Grehl, B. and Gibson, G.E. (1991) Neurobiol. Aging 12, 469-473.

147 Shimohama, S., Fujimoto, S., Taniguchi, T. and Kimura, J. (1992) Brain Res. 579, 347-349.

148 Jolles, J., Bothmer, J., Markerink, M. and Ravid, R. (1992) J. Neurochem. 58, 2326-2329.

149 Bothmer, J., Markerink, M. and Jolles, J. (in press) Dementia.

150 Bothmer, J., Markerink, M. and Jolles, J. (1992) J. Neurochem. 57 (suppl.), 44.

151 Bush, A.I., Beyreuther, K. and Masters, C. (1991) in Alzheimer's disease: Basic mechanisms, diagnosis and therapeutic strategies (Igbal, K., McLachlan, D.R.C., Winblad, B. and Wisniewski, H.M., eds.), pp. 547-556. J. Wiley \& Sons, Chichester, U.K.

152 Bothmer J., Markerink, M., Coppens, R. and Jolles, J. (1993) Mol. Chem. Neuropathol. 19, 249-258.

153 Bothmer J., Jolles, J., Markerink, M. and Ravid, R. (1993) in Alzheimer's disease: Advances in clinical and basic research (Corain, B., Iqbal, K., Nicolini, M., Winblad, B., Wisniewski, H. and Zatta, P., eds.), pp. 325-331. Wiley, Chichester, UK.

154 Young, L.T., Kish, S.J., Li, P.P. and Warsh, J.J. (1988) Neurosci. Lett. 94, 198-202.

155 Colvin, R.A., Bennett, J.W., Colvin, S.L., Allen, R.A., Martinez, J. and Miner, G.D. (1991) Brain Res. 543, 139-147.

156 Mattson, M.P., Rychlik, B. and Engle, M.G. (1991) in Alzheimer's disease: Basic mechanisms, diagnosis and therapeutic strategies (Igbal, K., McLachlan, D.R.C., Winblad, B. and Wisniewski, H.M., eds.), pp. 191-198. Wiley, Chichester, UK.

157 Baudier, J., Lee, S.-H. and Cole, R.D. (1987) J. Biol. Chem. 262, 17584-17590.

158 Hoshi, M., Nishida, E., Miyata, Y., Sakai, H., Miyoshi, T., Ogawara, H. and Akiyama, T. (1987) FEBS Lett. 217, 237-241.

159 Sihag, R.K., Jeng, A.Y. and Nixon, R.A. (1988) FEBS Lett. 233, 181-185.

160 Georges, E., Lindenbaum, M.H., Sacher, M.G., Trifaro, J.-M. and Mushynski, W.E. (1989) J. Neurochem. 52, 1156-1161.

161 Gandy, S., Czernik, A.J. and Greengard, P. (1988) Proc. Natl. Acad. Sci. USA 85, 6218-6221.

162 Masliah, E., Cole, G.M., Shimohama, S., Hansen, L., DeTeresa, R., Terry, R.D. and Saitoh, T. (1990) J. Neurosci. 10, 2113-2124.

163 Clark, E.A., Leach, K.L., Trojanowski, J.Q. and Lee, V.M.-Y. (1991) Lab. Invest. 64, 35-44.

164 Masliah, E., Cole, G.M., Hansen, L.A., Mallory, M., Terry, R.D. and Saitoh, T. (1991) J. Neurosci. 11, 2759-2767. 
165 Tanaka, S.-i., Tominaga, I., Yasuda, I., Kishimoto, A. and Nishizuka, Y. (1991) FEBS Lett. 294, 267-270.

166 Cole, G., Dobkins, K.R., Hansen, L.A., Terry, R.D. and Saitoh, T. (1988) Brain Res. 452, 165-174.

167 Cochet, C., Gill, G.N., Meisenhelder, J., Cooper, J.A. and Hunter, T. (1984) J. Biol. Chem. 259, 2553-2558.

168 Northwood, I.C. and Davis, R.J. (1989) J. Biol. Chem. 264. $5746-5750$.

169 Shapiro, I.P., Masliah, E. and Saitoh, T. (1991) J. Neurochem. $56,1154-1162$.

170 Holtzman, D.M. and Mobley, W.C. (1991) TIBS 16, 140-144.

171 Grundke-Iqbal, I., Iqbal, K., Tung, Y.-C., Quinlan, M., Wisniewski, H.M. and Binder, L.I. (1986) Proc. Natl. Acad. Sci USA 83, 4913-4917.

172 Kosik, K.S., Joachim, C.L. and Selkoe, D.J. (1986) Proc. Natl. Acad. Sci. USA 83, 4044-4048.

173 Wood, J.G., Mirra, S.S., Pollock, N.J. and Binder, L.I. (1986) Proc. Natl. Acad. Sci. USA 83, 4040-4043.

174 Weingarten, M.D., Lockwood, A.H., Hwo, S.-Y. and Kirschner, M.W. (1975) Proc. Natl. Acad. Sci. USA 72, 1858-1862.

175 Ihara, Y., Nukina, N., Miura, R. and Ogawara, M. (1986) J. Biochem. Tokyo 99, 1807-1810

176 Baudier, J. and Cole, R.D. (1987) J. Biol. Chem. 262, 1757717583.
177 Lee, V.M.-Y., Otvos, L., Schmidt, M.L. and Trojanowski. J.O. (1988) Proc. Natl. Acad. Sci. USA 85, 7384-7388.

178 Bancher, C., Brunner, C., Lassmann, H., Budka. H., Jellinger. K., Wiche, G., Seitelberger, F., Grundke-lqbal, 1., Iqbal, K. and Wisniewski, H.M. (1989) Brain Res. 477, 90-99.

179 Brion, J.-P., Hanger, D.P., Couck, A.-M. and Anderton, B.H. (1991) Biochem. J. 279, 831-836.

180 Hanger, D.P., Brion, J.-P., Gallo, J.-M., Cairns, N.J., Luthert. P.J. and Anderton, B.H. (1991) Biochem. J. 275, 99-104.

181 Ksiezak-Reding, H., Binder, L.I. and Yen, S.-H. (1990) J. Neurosci. Res. 25, 420-430.

182 Literski. J.M. and Johnson, G.V.W. (1992) J. Biol. Chem. 267. $1563-1568$.

183 Flood, D.G., Buell, S.J., Horwitz, G.J. and Coleman, P.D. (1987) Brain Res. 402, 205-216.

184 Kosik, K.S., Orecchio, L.D., Bakalis, S. and Neve, R.L. (1989) Neuron 2, 1389-1397.

185 Galloway, P. and Perry, G. (1991) Brain Res. 541, 347-349.

186 Mulvihill, P. and Perry, G. (1989) Brain Res. 484, 150-156.

187 Kosik, K.S., Duffy, L.K., Dowling, M.M., Abraham, C., McCluskey, A. and Selkoe. D.J. (1984) Proc. Natl. Acad. Sci. USA 81. 7941-7945.

188 Burnett, D.M., Daniell, L.C. and Zahniser, N.R. (1990) Mol. Pharmacol. 37, 566-571. 